\title{
Bybelse Teologie en skuldbelydenis
}

\author{
P M Venter \\ Departement Ou-Testamentiese Wetenskap (Afd A) \\ Universiteit van Pretoria
}

\begin{abstract}
Biblical Theology and confession of guilt

Investigating the probable contents of a confession of guilt, this article pays attention to the contemporary paradign shift in theology and hie viewpoint of

Black Theology as interlocutor. The trends in Bblical Theology and the role played in it by the conversation between Jews and Christians th the post-lolocaust era are studied. The prayers in Bzar 9, Nehemiah 9 and Danial 9 are investigated and it is concluded that confession of guill is Inked to doxology and confession in so far as the righteoussness, mercy and grace of Cod are concerned: Taking these trends in account a proposal is made whih regard to the possible contents of a confession of guilt.
\end{abstract}

\section{INLEIDING}

Die vraagstuk waarmee ek hier werk, is wat die bydrae uit die hoek van die Bybelșe Teologie kan wees vir die inhoud en formulering van 'n skuldbelydenis in die postapartheidsera in Suid-Afrika. Dit gaan nie hier oor die wenslikheid of die tydigheid van sodanige skuldbelydenis nie. Daaroor kan die artikel van I W C van Wyk (1997: 1399-1436) gelees word.

Die uitgangspunt wat ek hier volg, is dat 'n skuldbelydenis voor alles 'n belydenis is. My gevolgtrekking is ook dat 'n skuldbelydenis binne 'n geloofsbelydenis bevat moet wees. Soos elke vorige belydenis van die Christelike kerk is 'n geloofsbelydenis die produk van teologiese nadenke vanuit die Bybel binne 'n bepaalde historiese konteks, uitgedruk in die bepaalde teologiese idioom van daardie tyd.

So gesien, vereis die nadenke oor 'n skuldbelydenis besinning oor die teologiese idioom van ons tyd en die tendense van die konteks waarin ons lewe. Vir 'n reformatoriese teologie vereis dit ook besinning oor Skrifinhoud en Skrifgebruik. Daarvoor gee ek, naas die bostaande sake, ook aandag aan die subdissipline van Bybelse 
Teologie (om redes wat mettergaan duidelik sal word) en aan 'n paar skuldbelydenisse uit die Ou Testament. Dit sal ons uitbring by enkele riglyne wat neergelê kan word vir die formulering van 'n kontemporêre skuldbelydenis en 'n voorstel oor die inhoud van so 'n belydenis, indien daarop besluit word.

\section{TEOLOGIESE TENDENSE}

\section{1 'n Paradigmaskuif}

Daar het in die teologie 'n paradigmaskuif plaasgevind (vgl o a Van Aarde 1995). Daar word nie net nuwe vrae gevra nie, maar die vrae word op 'n heel nuwe manier geformuleer en beantwoord. In die hermeneutiek word hierdie verskuiwing verteenwoordig deur 'n skuif van die fokuspunt weg van die teks af na die aktiewe en skeppende rol van die leser van die teks. Soos David Kelsey uitgewys het, funksioneer Skrifgesag altyd in terme van die basiese verwagtings en verbintenisse van die leser (vgl Juel 1994:96). In die leesproses word die teks verbind aan die historiese moment van lesers en die praktyk waarin hulle staan.

Deur die insette van mense soos Gadamer, Habermas, Kuhn, Feyerabend, Lakatos, Winch, Arendts en Rorty is die optimisme van beide objektivisme en relativisme laat vaar ten gunste van 'n praktykgerigte waarheidsbegrip. Dit gaan oor 'n “... practical and communal knowledge which tests the truth of a position by asking whether and how it might apply to the practice, that is, the history, of the community" (West 1991:22).

Die skuif na lesers en gevolglik ook die sosiale gemeenskap waarin hulle leef, het egter nie net ' $n$ verskuiwing van fokuspunt vir die teologie meegebring nie, maar ook 'n verandering in epistemologie. Met epistemologie word verstaan die mees fundamentele aspek van wetenskaplike werk "defining the ground rules of the quest for truth" (Frostin 1988:3). Die oorsprong, struktuur, metodes en geldigheid van kennis kom sterk onder die soeklig. Die soeke na waarheid word op 'n radikaal nuwe manier aangepak. Die bepaalde situasie wat ervaar word, geld as die vertrekpunt van waaruit geredeneer word. Sedert die Renaissance is idees as die vertrekpunt van teologie geneem. Tans is dit eerder sosiale verhoudings wat in die fokuspunt staan. Die waarheid is nie langer meer verhewe of universele en altyd geldende idees nie, maar dit wat uitwerk, wat iets doen in die praktiese situasie. Ietwat anders gestel: "Deep 
convictions in contemporary society relegate the Bible to the realm of the meaningful, not truthful" (Juel 1994:96).

'n Liggaam, soos EATWOT ("Ecumenical Association of Third World Theologians" ("... a forum of the different varieties of Third World theologies" - Frostin 1988:2), het vanaf die ontstaan daarvan in die sewentigerjare, gewerk vir 'n konteksbepaalde epistemologiese verandering. Volgens hulle beredenering het die gevestigde metodes en epistemologie van teologiebeoefening van Europa en NoordAmerika uit die bepaalde situasie van daardie lande ontstaan. Die lande van die Derde Wêreld moet egter vanuit die realiteite waarin hulle self leef, 'n eie epistemologie ontwikkel. Onder "Derde Wêreld" word egter nie net 'n geografiese kollektiwiteit verstaan nie, maar ook 'n sosio-ekonomiese (onderontwikkelde), politieke (eiesoortige) en teologiese ("from the underside of history" - Frostin 1988:5) kategorie. Vir ' $n$ feminis soos Fiorenza, impliseer die verandering 'n transformasie van scientific imagination. Die nuwe paradigma moet ' $n$ eie institusionele strukture en ondersteuningstelsels produseer. 'n Paternalisties-bepaalde paradigma, gekoppel aan manlike, hetero-seksuele, westerse en wit magstrukture, moet vervang word met 'n nuwe paradigma wat nuwe strukture skep. Dit bring 'n bepaalde commitment mee van verantwoordelikheid en solidariteit met die gemeenskap wat as gespreksgenote gekies is.

Volgens Frostin (1998) is die huidige teologiese debat daarom 'n konflik tussen 'n gevestigde hegemoniese (heersende) paradigma en 'n kontra-hegemoniese paradigma wat vanuit die periferie van mag afkomstig is. Die gevestigde metodes van teologie in Europa en Noord-Amerika word nie net uitgedaag deur die bevrydingsteologieë uit Asië, Afrika en Latyns-Amerika nie, maar ook vanuit eie geledere deur die feministiese en werkersbewegings van die Eerste Wêreld. Die tradisionele teologie moet herposisioneer word binne 'n pluralistiese post-moderne gemeenskap waarin dit die vanselfsprekende hegemonie verloor het.

In terme van die rol van meesternarratiewe en kontranarratiewe (vgl Breytenbach 1997) is daar ' $n$ magsverskuiwing aan die gang in die teologie. Selfs wanneer Van Aarde (1995:14) praat van 'n "paradigmatiese verskuiwing van middelmatige aard" en hy 'n "selektiewe afskeid" van die moderniteit bepleit deur 'n post-moderne teologie te bedryf, akkommodeer hy hierdie skuif na die sosiale konteks. Hy wil die dialektiese teologie handhaaf en verruim (vgl Van Aarde 1995:26), maar in terme van “... die kontekstualisering van dialektiese denke" (Van Aarde 1995:14) Die dialektiese teologie behoort aangevul te word met "...elemente van die ekumeniese en kontekstuele teologie ..." (Van Aarde 1995:26). Dit impliseer dat nie net die pragmatiese 
en affektiewe dimensies van menswees naas die kognitiewe beklemtoon sal word nie (vgl Van Aarde 1995:20), maar ook die bowesintuiglike werklikheid sowel as die immanente werklikheid (vgl Van Aarde 1995:17). Op 'n holistiese skaal kan die teologie dan kerk en gemeenskap bedien, op sosiale en politieke terrein simmetriese verhoudings bewerk (sonder dat dit neerkom op die social gospel van die sestigerjare - vgl Van Aarde 1995:25), versoenende verskeidenheid met deernis en barmhartigheid begelei, op die vlak van die ekumene verskeidenheid te bowe kom sodat onderlinge gemeenskap met die lewende Heer kan plaasvind en binne die intergodsdienstige debat die apostolêre en missionêre taak van die kerk volvoer.

\subsection{Die Derde Wêreld en Swart Teologie}

Volgens Frostin (1988:6-10) word 'n nuwe paradigma in die Derde Wêreld ontwikkel.

Dit word gekenmerk aan vyf onderling verbonde velde van belang: die keuse van gespreksgenote, die persepsie van God, die sosiale analise van konflik, die keuse van teologiese gereedskap en die verhouding tussen teologie en praktyk. Hierdie nuwe paradigma wyk in twee opsigte van die gevestigde metodes van teologie af. Dit is eerstens eerder sosiale verhoudings as idees, wat as die crux van teologie funksioneer. Die vraag is veel meer na wie die gespreksgenote ("interlocutors") is wat die teologiese vrae vra, as na die dinge wat gevra word. Tweedens is die keuse vir gepreksgenote van die teologie, anders as die Weste (by name Schleiermacher) se gekultiveerde geloofskritici en ongelowiges, eerder die gemarginaliseerdes, die magloses, die armes en dié wat geëksploiteer is. Die situasie waarin hulle leef, hulle realiteit, is altyd een van struggle. Dit gaan egter om meer as net herkenning van hierdie gespreksgenote en beskrywing van hulle lot. Met hulle en hulle situasie moet sodanig geïdentifiseer word, dat die opdrag van teologie gesien word as een wat inspreek in hulle omstandighede en probeer om dit te verander. Vir iemand soos Gerald West (1991:63-79) impliseer dit in Suid-Afrika verantwoordelikheid van die teologie teenoor die swart gemeenskap en solidariteit met hulle bestaan. Daar is 'n commitment, verantwoordelikheid en solidariteit met hulle wat die agenda vir die Bybelse hermeneutiek bepaal.

Wanneer die skuif in teologie dan na die praktyk is en die gesprek gevoer moet word binne 'n plurale gemeenskap van gelykberegtigdes, lê dit op ons weg om deeglik kennis te neem van die perpektiewe wat onder die gespreksgenote in Swart Teologie nagehou word. As die praktyk 'n aanklag lê teen die apartheidsbeleid en dit 
staaf met getuienisse voor die Waarheids- en Versoeningskommissie, dan is dit gepas om die kritiek vanuit Swart Teologie aan te hoor, ten einde teologies daarop te antwoord in 'n eietydse idioom wat vir almal verstaanbaar is. Vir hierdie inligting verlaat ons ons op die werk van Frostin (1988).

Frostin onderskei tussen die kritiek wat vanuit liberale teologie op apartheid gekom het en dié wat uit die Swart Teologie kom: "While racism in the liberal paradigm is described as the cause of exploitation, black theologians understand it as the justification of exploitation" (Frostin 1988:135). Terwyl die liberale teologie die stelsel van apartheid ideë-matig sien as die miskenning van menseregte en daarom die oorsaak van wanpraktyke, sien Swart Teologie dit pragmaties-holisties as 'n praktyk wat nie die heil van die gemeenskap bevorder nie, maar afgode, soos winsbejag, rasse-identiteit en nasionalisme, dien (vgl Frostin 1988:136).

Swart Teologie sien denke en aksie, teorie en praktyk in holistiese lig. In hierdie teologie word epistemologiese, antropologiese en teologiese belange saamgesnoer. "The selfaffirmation derived from creation faith is both theocentric and humanistic; moreover, it has inspired a new perception of reality with certain truth claims" (Frostin 1988:103). In Swart bewussyn en teologisering word alles in terme van konflik gesien. Op multidimensionele vlakke word konflik uitgewys: ekonomies (ryk-arm), klasse (kapitaliste-proletariaat), geografies (noord-suid), seksisties (manlikvroulik), etnies (wit-swart) en kultureel (dominerende en gedomineerde kultuur). Dit beteken geen a-historise teologie nie, maar dat “... the theologian must analyze his or her role in the social conflicts, to discover how the context shapes the perception of theologically relevant issues" (Frostin 1988:9). . Met behulp van die sosiale wetenskappe word in hierdie kontekstueel gerigte teologie beoordeel aan wie se kant God is en wat die afgode is wat vermy moet word. Dit gaan in die teologie om ortopraksis, om die proses van transformasie en konstruksie van 'n nuwe wêreld waarin daar geveg word teen "... an idolatrous submission to systems of oppression" (Frostin 1988:7).

In die Swart ervaring van Wit magstrukture het vier teologiese konsepte 'n sentrale rol gespeel: afgodsdiens, kettery, sonde en laster. Die afgode opponeer die wil van God en bedreig die heil van die gemeenskap deur afgodiese praktyke. "When apartheid is described as idolatry, it is suggested that faith in God is denied by allegiances to rival gods" (Frostin 1988:105). Die stelsel van apartheid word voor alles in terme van die verhoudingsgedrag tussen groepe beoordeel. Rassisme as die ver- 
steuring van verhoudings tussen groepe, loop histories saam met die verbreiding van die Europese kultuur, kolonialisme en kapitalisme. Rasidentiteit het hand aan hand hiermee geloop en is een van die funksionele faktore in die oorheersing van een groep deur ' $n$ ander. Daarom verwerp Steve Biko die Anglo-Boere kultuur omdat dit vir hom by albei groepe steeds gaan om eksploitasie van die swart groep. Ook by Boesak gaan dit om die Westerse wittes wat almal aandadig aan rassisme gehou word. Engelse en Afrikaners verskil slegs in graad van skuldigheid aan rassisme.

Daarnaas het Swart Teologie ook kritiek op die ekonomiese struktuur. Die Wit magstruktuur word uit hierdie oord beskuldig van ekonomiese eiebelang en hebsug. Kapitalistiese eksploitiewe waardes lê aan die wortel van rassisme. Die prekoloniale sosiale patroon het op mededeelsaamheid gewerk en nie op individuele selfverryking nie. Swart Teologie kies vir sosialisme in die sin van 'n nie-eksploiterende, egalitariese ekonomiese stelsel wat krities staan teenoor gulsigheid en mededingende haat. Swart Teologie het nie probleme met die wins-georiënteerdeheid van die ekonomie nie, maar wel met die uitwerking daarvan op die teologie en die rasseverhoudings. Die ervaring van Swartes van die manier waarop die ekonomie uit Wit geledere bedryf word, is dat dit hulle van hulle menslikheid ontneem. Volgens hulle het die hebsug waarmee die ekonomie bedryf is, aanleiding gegee tot 'n etniese hiërargie wat geregverdig is deur ' $n$ ideologie van rassisme.

In die lig van die goeie bedoeling van apartheid om gelyke geleenthede vir verskillende groepe te skep, het iemand soos W A de Klerk op fundamentele ooreenkomste tussen Afrikaner nasionalisme en Swart bewussyn gewys. "The common denominator is found in 'the will to power' absolutized in theology" (Frostin 1988: 122). Afrikanernasionalisme kon as 'n teologie van bevryding en as kontekstuele teologie gedefinieer word. Die geveg teen die Britse Hoggenheimers en die poging om in die gegewe konteks selfstandigheid te kry, kon daarvan 'n kontekstuele teologie gemaak het. Die kritiek uit Swart teologie is dat dit nooit om goeie intensies gegaan het nie, maar dat volk, ras en wins, van groter belang was in apartheid as die wil van God soos Swart teologie dit verstaan. En dit is in Swart denke gelyk aan afgodediens. Hierdie negatiewe ervaring het gelei tot die demitologisering van Afrikanerdom en bevraagtekening van hulle eerbaarheid. Die apartheidsideologie is as 'n volksideologie ervaar wat dink in terme van die kollektiewe van volkere wat gesegregeer moet word en daarom in reëlregte konflik staan met die Swartes as kollektiewe groep. 
Ten spyte van die gemeenskaplikheid van 'n strewe om bevryding uit 'n situasie van onderdrukking, is dit ' $n$ bekende feit dat "... the dominant Afrikaner theology has never opted for the blacks as interlocutors" (Frostin 1988:125). Die apartheidprojek was antagonisties teenoor 'n teologiese refleksie wat op Swart ervaring gebaseer is. Boonop is daar 'n konflik tussen die dialektiese en digotomiese denke van die twee. Die tipiese Westerse denke onderskei digotomies tussen die verskillende dimensies van verlossing en poneer 'n diesseits en jenseits, 'n oorsaak en gevolg. Die Swart denke redeneer sinkronies en holisties en plaas alle gegewenhede dialektiese op een vlak (vgl Frostin 1988:195). Gutiérrez onderskei drie vlakke in die bevrydingsproses, naamlik dié van die sosio-politiese, historiese en geestelike. Daar is egter vir hom geen parallele of chronologiese skeiding tussen die drie nie. Kritiek op bevrydingsteologie as immannentisme of reduksionisme, beoordeel dit verkeerdelik vanuit 'n digotomiese raamwerk. Hierdie teologieë werk met 'n bepaalde ervaring wat Eerste-Wêreldse mense nie deel nie en daarom nie kan verstaan nie. Swart Teologie moet in eie terme verstaan word. "... the analyzed theologies integrate theology, anthropology, the economy, and epistemology into a holistic approach that differs markedly from the established pattern in Western theology. Hence, if a dichotomic grid were forced on these theologies, their internal logical would be destroyed" (Frostin 1988:197).

\section{3 'n Gesprek in Suid-Afrika}

Uit hierdie karakterisering van Swart teologie en die post-moderne skuif na pluralisme in die teologie wat hierbo aangetoon is, is dit duidelik dat ' $n$ teologiese gesprek tussen 'n Eerste Wêrelds-georiënteerde Wit kerk en 'n Derde Wêrelds-georiënteerde Swart kerk in Suid-Afrika "... cannot only be a discussion about theological ideas but must also interpret these ideas in the light of the contrast experiences" (Frostin 1988:103) (my aksentuering). Daar kan ook nie plek wees in hierdie gesprek vir 'n hegemoniese en bombastiese houding van ek-alleen-is-reg nie. Daar sal wat Frostin noem 'n bepaalde demokratiese weg gevolg moet word. "In an intercultural dialogue, based on equality and mutuality, the Western intellectual tradition will be seen as one voice among others, not as an absolute and infallible norm" (Frostin 1988:25).

Daar sal van Wit kant oor die nadelige uitwasse van apartheid verder gedink moet word as net in humanitêre of liberaal-teologiese terme. Daar sal nagedink moet word oor die Westerse beskawing as 'n produk van die Christendom en wat dit mee- 
gebring het. Daar sal nederig en fyn geluister moet word na presies wat die aanklag uit Afrika in teologiese terme is. In die oorweging en formulering van 'n skuldbelydenis sal meer gemaak moet word van die Afrika-konteks waarin geteologiseer word en van die teologiese vraagstukke wat daar op hierdie vasteland bestaan. Daar sal met Swart teologie in debat getree moet word.

Ook op die terrein van die afsonderlike vakgebiede van teologie, van waaruit daar bygedra word tot die nadenke oor sodanige belydenis, sal daar meer gemaak moet word van die konteks waarin gewerk word. Deist het in 1991 reeds uitgewys dat daar wat die vakbeoefening van die Ou Testament betref, nog nie werklik 'n eie inheemse Suid-Afrikaanse tradisie van Ou Testament-navorsing ontwikkel het nie. Sover terug as 1973 het sendelinge al die behoefte uitgewys om binne 'n nuwe en meer kontekstueel bepaalde raamwerk die Bybel te interpreteer. "Today, nearly twenty years later we, as Old Testament scholars, have yet to take cognisance of our African context" (Deist 1992:317). Daar sal ernstig aandag gegee moet word aan die vrae wat ons Afrika-konteks opwerp. Hierdie vrae sal egter ook op ons vakbenadering en vakmetodiek inwerk. "Allowing our own context to play its rightful part in our scholarly work will indeed bring about a different structure of consciousness, and therefore a different meaning to "understanding the Old Testament" ... (Deist 1992: 318).

\section{DIE BYDRAE VAN BYBELSE TEOLOGIE}

\section{1 'n Skuif in Bybelse teologie}

Sedert Gabler in 1787 is daar al gepoog om teenoor en naas die sistematiese teologie met 'n selfstandige Bybelse Teologie vorendag te kom. Die ontwerp van onderskeidelik 'n Ou-Testamentiese en Nuwe-Testamentiese Teologie loop kragtens die komplementariteit van hulle benamings (oud en nuut) eventueel uit op 'n gesamentlike Bybelse Teologie. Daar bestaan egter tot op hede geen eenstemmigheid oor die omvang en metode van so 'n Bybelse Teologie nie.

Den Hertog gee in 'n kantaantekening 'n werkbare definisie van Bybelse Teologie: "Het principe hiervan zouden we als volg kunnen formuleren: een inzicht van meer algemene, 'theologische' aard gewonnen aan de uitleg van één of meer bijbelteksten kan als leidraad functioneren voor de uitleg van een andere bijbelteks. 
Vooronderstelling hierbij is dat de bijbelse teksten, al hun verscheidenheid ten spijt, toch niet voor niks samegevoegd zijn" (Den Hertog 1996:16).

Bybelse Teologie was van die begin af "... affected by currents in church life, theology generally, and academic trends" (Reuman 1991a:6). Soos Gabler op sy dag in die lig van die Renaissance die gedagte teengestaan het dat die Bybel ewige universele waardes aanbied, speel Protestantse liberalisme, neo-ortodoksisme, bevrydingsteologie en Swart Teologie 'n rol in die bedryf van Bybelse Teologie. Net soos by die teologie oor die algemeen, het daar ook by die Bybelse Teologie 'n skuif gekom gedurende die laaste dekades. Daar word nie net meer bespiegel oor die aard van die Skrif en wat agter die teks lê nie, maar ook oor neigings in die kritiek. Die lokus van gesag het saam met die uitbreiding van die gespreksgenote verskuif. "The judgments in criticism are no longer made solely by white North American males, nor are 'our experiences' and the interconnection of events seen any longer exclusively from such vantage points; they are now 'under new management"' (Reuman 1991a: 12; vgl ook Trible 1991:55). Brueggemann (1997:4) praat van 'n 'new past hegemonic situation' waarin die dominansie van een vertolking plek gemaak het vir 'n groot verskeidenheid van interpretasies wat almal ewe legitiem is.

Ook in Bybelse Teologie het die skuif gekom na die leesaksie en die lewenskonteks van die Bybelleser. Volgens Reuman (1991a) is daar 'n beweging weg van historiese kritiek na 'n nuwe literêre benadering. Sweeney (1998:142) verwys na Leo Perdue se uitdrukking "collapse of history". Dit is teweeggebring deur 'n horde nuwe tegnieke wat elders ontwikkel is en op die Bybel toegepas word, soos narratologie, retoriese analise, strukturalisme en die klem op sosiale benaderings en sosiologiese verduideliking van verskynsels. Sweeney (1998:143) stel dit meer epistemologies:

In an increasingly pluralistic climate that acknowledges the great diversities in the means by which human beings perceive their world and establish truth claims, historical criticism has now become not the exclusive means to establish legitimate interpretation of the Bible, but one among an ever growing number of reading strategies that are employed to interpet the Bible, such as liberation and feminist hermeneutics, new literary and reader response criticism, canonical hermeneutics, and others. 
Namate hierdie verskeidenheid van tegnieke gebruik is, het dit al meer aan die lig gekom dat die Bybel "profoundly plurivocal" (Brueggemann 1997:5) is. Hierdie meerstemmigheid van die Skrif korreleer egter met die verskeidenheid van gebruikers van die Skrif: "This plurivocal quality intrinsic to the text is now deeply reflected in pluralism in interpretation, a plurality of methods, a plurality of interpreting communities, and a plurality of provisional grids of interpretation ..." (Brueggemann 1997:5). Die groter gerigtheid op die praktyk speel in die beoefening van Bybelse Teologie 'n steeds groter rol. Enersyds word die daaglikse realiteit meer in berekening gebring en andersyds word Bybelse Teologie al meer op die alledaagse vlak in werking gestel.

Trible (1991:55) som die tendense so op: “... it has grown through experimentation. It includes conversation between sociology and theology, discussion of canon, and development of bipolar categories for encompassing scriptural diversity. More broadly, biblical theology has begun to converse with the world." Politieke, sosiale en ekonomiese veranderings het hierin 'n groot rol gespeel. Reuman wys daarop dat in die sestigerjare-sewentigerjare sake soos burgerrregte, omgewingsake, sosiale etiek en die vraag na God se werk vandag op die voorgrond begin kom het (vgl Reuman 1991b:188). Die tradisionele Bybelse Teologie het hierop nie antwoorde gehad nie en nuwe weë moes gesoek word.

Bybelse Teologie word gebruik in 'n volledig sekulêre en pluralistiese konteks om aan te dui wat die Bybel leer. Die kerk en die akademie sal altyd mense nodig hê “... who will periodically venture to state what a reading of the Hebrew Scriptures, New Testament, or the whole Bible involves in and for the current scene" (Reuman 1991b:201). Aan institute vir opleiding word dit gebruik om die atomistiese kennis van Ou en Nuwe Testament nader en met mekaar in verband te bring. Reuman is daarvan oortuig dat “... the many ways of doing biblical theology as a discipline of the two Testaments will not achieve the desired impact unless related to, and done as, practical theology" (Reuman 1991a:20). Dit kan wel in samehang met sistematiese teologie staan. Dit is egter in die toets van die praktyk van kerklike verkondiging waar die sukses of mislukking van Bybelse Teologie bepaal sal word.

\subsection{Kanon, feminisme en Jode}

Bevrydings- en feministiese teologie het die agenda van Bybelse Teologie verander. "Issues such as ecology, medical ethics, creationism, and spirituality press for dia- 
logue. Racial, religious, and sexual perspectives also enter the discussion. AfricanAmericans, Asians and Jews, for instance, shape the discipline differently from traditional proponents. In short, biblical theology by whatever definition, method, or point of view, must grapple with contemporary hermeneutics” (Trible 1991:55).

Dit het noodwendig meegebring dat Bybelse Teologie ook begin wegbeweeg het van die poging om 'n teologie van die hele Bybel te skryf. Daar word eerder vanuit 'n geheel Bybelse perspektief geskryf oor onderwerpe soos wet, geregtigheid, vrede, seën, teenwoordigheid (vgl Reuman 1991b:185-208). Hoewel Bybelse Teologie vanweë die inherente aard daarvan geneig is tot tematisering, wat groter is as die afsonderlike Skrifgedeeltes ten einde gesag op te eis ("truth claims, normative claims, substantive claims" - Brueggemann 1997:5), weerstaan die teks self, vanweë die meerstemmigheid daarvan, alle reduksionistiese tematiserings. Enige tematisering van die Bybelse inhoude is altyd gelokaliseerd, tydsgebonde en uiters voorlopig. Dit is eerder 'n prosesmatige ("processive" - Brueggemann 1997:5) interaksie en dialoog tussen God en die res wat onophoudelik voortgaan. Dit is 'n dialektiese proses van "core testimony" (Brueggemann 1997:5) en "counter testimony" (Brueggemann 1997:

5) waarin basiese sake aan die lig kom en weer in balans getrek word deur teen getuienisse wat die ander kant van die selfde saak belig. (Op hierdie teenstellings sal ons aan die einde van die artikel weer terugkom om binne die kategorie van lofliedklaaglied aandag te gee aan die paar doksologie-skuldbelydenis.).

Tussen al die moontlikhede waarvolgens Bybelse Teologie benader kan word, dui Reuman (1991b:191-3) drie hoof benaderings aan:

- Kanonkritiek

- Feministiese en bevrydingsteologie

- Die gesprek tussen Christendom en Jodedom.

\subsection{Kanonkritiek}

Kanonkritiek werk enersyds met die uitwerking van die kanonvorm op die leesproses (Childs) en andersyds met die motiewe agter die proses van kanonvorming (Sanders). Vir albei benaderings is die geloofsgemeenskap van wesenlike belang. Wanneer Bybelse Teologie poog "... to articulate the faith of the authors of the canonical text" (Kysar 1991:144-5), is dit 'n gemeenskapsaangeleentheid. Dit is die artikulering van 
standpunte wat geskryf is "... out of a community that had preserved a tradition and for a community that needed to hear that tradition interpreted for its needs" (Kysar 1991;146). Hoewel hierdie benadering volgens Reuman (1991b:192) die beste geskik is vir 'n Bybelse Teologie, word die vrae hier bepaal deur die Bybelse tradisie en nie die huidige gemeenskap nie. Die klem op die kanoniserende geloofsgemeenskap sluit egter baie nou aan by die gesprek met die Jode waar die noodsaak om die Bybel in die Joodsheid daarvan te sien, baie sterk beklemtoon word.

\subsection{Feministiese teologie}

In bevrydings- en feministiese teologie word daar aandag gegee aan “... "readeroriented" criticism and ... conventional historical literary methodologies" (Reuman 1991b:191). Vir hierdie benadering is Bybelse Teologie “... never 'pure' or 'simple' because it arises situationally out of the theologian's world on the margins of society or her experiences as one patriarchally oppressed" (Reuman 1991a:17). By bevrydingsteologie is die ekonomies-behoeftige en politieke onderdrukte die uitgangspunt en by feministiese teologie die negatiewe ervarings van die vrou. "Spesifieke ekologiese, kulturele en politieke omstandighede speel in op die lees van die Bybel" (Dreyer 1998:64). Die bevrydingsteologie toon Latyns-Amerikaanse, Afrika en Asiatiese variasies. Dit reflekteer klassieke literatuur, filosofieë en tradisionele teologieë. Temas wat hier herhaaldelik voorkom is dié van die eksodus en die historiese Jesus wat sosio-polities verstaan word, Christologie, ryk en arm, egalitarianisme. Die gedagte in feministiese teologie is dat daar 'n "kreatiewe botsing" moet plaasvind tussen die tradisie uit die verlede, ervaring en kreatiewe verbeelding, maar dan nou met baie meer klem op die ervaring van vrouens as gemarginaliseerdes wat vir lank stil gemaak was in die kerk (vgl Reuman 1991a:17).

Dreyer (1998:64) wys op die probleem dat “ [K]ontekstuele teologie kan maklik in die ideologiese strik val om die oplossings vir negatiewe ervarings te sien in 'n totale afskeid neem van die vorige paradigma." Hierdie benadering word egter dikwels opgehaal in die gesprek met die Jode omdat dit 'n verouderde hegemoniese houding van supersessionisme teengaan en die toleransie kweek om ook aan die gemarginaliseerde Jode ruimte in die teologiese gesprek te gee. 


\subsection{Die gespek met die Jode}

Die holocaust, ook genoem shoah, bepaald die gebeure by Auschwitz, het gelei tot 'n wêreldwye gesprek tussen Christene en Jode. Die Tweede Vatikaanse Konsilie van 1965 met die "Declaration on the relationship of the Church to Non-Christian religions", die verslag van hulle werkgroep oor die verhouding tussen Jode en Christene aan die Kommisie van Geloof en Orde van die Wêreldraad van Kerke in 1967 en die eerste internasionale simposium oor die holocaust in 1974 in New York, het hierdie gesprek gestimuleer en talle publikasies oor die onderwerp het verskyn.

Die holocaust het teologiese vrae vir beide Jode en Christene gebring. Vir albei is die mees wesenlike vraagstuk dié van die teenwoordigheid van God in die geskiedenis van die wêreld. Vir Jode is die groot vraagstuk van wat hulle aanvoel as 'n oneweredigheid tussen hulle sonde en die teregstelling van ses miljoen Jode in die veertigerjare. Hulle aanvaar die feitelikheid van kwaad en oortreding. Dit gaan egter oor die redeloosheid van God en die ondeurgrondbaarheid van hulle sonde wat so iets oor hulle gebring het. God se weë is onkenbaar en 'n misterie. Verskillende Joodse groepe neem verskillende standpunte in: God is dood en kon niks aan die holocaust doen nie; God het die Jode aan hulle eie lot oorgelaat; dit het die goeie uit die Jode gebring. Meer radikaal nog is die oortuiging dat lyding enige sin het, finaal van die tafel gevee is. Dit het die einde gebring van die beskouing van "human suffering as a positive religious category and thereby the revolutionary effacement of much accepted theodicean reflection" (Eckardt 1990:158). In die aangesig van die hel van gaskamers en krematoriums is die tradisionele martelaarskap gestroop van alle sin en betekenis.

Sedert Auschwitz is erken hoe die vooropgesetheid van die Christendom tot die veragting van die Jode bygedra het "... und deshalb für das Geschehene mitverantwortlich ist" (Van der Osten-Sacken 1991: 245). "After Auscwitz there can be no more excuses. Christendom cannot avoid clear admission of its guilt" (Küng 1991: 263). Daar word van "Mitschuld" gepraat. Dit is verstommend dat die Jode aangekla staan van die vervolging en verdrukking van Jesus in die kruisgebeure, maar dat Christene self bystaan waar miljoene Jode uitgewis word. Dit maak “... Christian participation in and responsibility for the Holocaust all the more horrible and revolting" (Harrington 1991:84). As die vraag van Jode dié is oor die redeloosheid van hulle lot, dan is die vraag van Christene aan hulleself oor die redeloosheid van hulle sonde en die ongerealiseerdheid van werklike verlossing in hulle lewe. 
Uit die noodsaak wat ontstaan het vir "... not merely humanitarian but theological discussion with Jews ..." (Küng 1991:265), het ook die dringendheid ontstaan vir teologiese introspeksie van die Christendom. Eckardt (1990:155) meen dat "The primary Christian challenge in the shadow of the Shoah is not simply to demythologize the Christian tradition but to deideologize it - to overcome its super-sessionist elitism." Die shoah moet die Christene tot uiters kritiese herbesinning roep. Dit konfronteer hulle met hulleself en met die dade waaraan hulle op bepaalde wyse deel gehad het wat in die naam van die Christendom gepleeg is. Dit vra die eenvoudige vraag: "Is the Christian gospel any longer morally credible?" (Eckardt 1990:161). Dit sit 'n diepgrypende proses aan die gang wat vra vir 'n herdefinisie van die Christendom: “... such a rethinking only can be the beginning of a re-examination of the whole edifice of Christian theology we live in" (Rendtorff 1993:164).

Die nadenke oor die holocaust het volgens Rendtorff (1993:160) 'n “... heuristic function that opens the eyes for hidden problems and insights." Daar is veral drie probleme wat na vore kom: anti-Semitisme, 'n hegemoniese gesindheid en vervreemding van die werklikheid.

Antisemitisme: Volgens Sweeney (1998:146) was die uitwissing van die Jode gedeeltelik beïnvloed “... by theological premises articulated within Christianity and identified as universal or normative during the Enlightenment." Von Waldow meen egter dat dit nog veel verder teruggaan in die geskiedenis. Die holocaust is vir_hom die simptoom van iets wat baie langer en dieper by die Christendom aanwesig is, naamlik anti-Semitisme: "[It] can no longer be denied that Christian anti-Semitism contributed to the Holocaust in much the same way as it contributed to all the other pogroms throughout the centuries in the so called Christian Occident" (Von Waldow 1995:143, vgl ook Kessler 1996:3.8). Brueggemann ruil oorsaak en gevolg om, sodat Christelike hegemonie as die grootste kanker uitgewys word. Hy wys boonop uit dat hierdie houding selfvernietigend vir die Christendom is. Die verskille tussen Jode en Christene in kulturele, historiese en politieke realiteite is "... propelled by Christian hegemony and domination, which has produced not only ant-Semitism and supersessionist interpretation, but also a serious misconstrual of our own tradition" (Brueggemann 1997:8) (my beklemtoning).

Die anti-Semitiese en anti-Joodse houding het nie net ander mense vernietig nie, maar erger nog, dit het die Christendom self begin verwoes. Daar is al meer raakgesien hoe anti-Semitisme wat uit Christelike bodem gevoed is, tegelyk ook die 
Christelike identiteit verlore laat gaan het. In die vernuwing van die verhouding tussen Jode en Christene lê ook 'n (her)ontdekking van Christelike identiteit (vgl Van der Osten-Sacken 1991:245-247). Dit is juis een van die skerpste snypunte in die insig van die Mitschuld aan die holocaust dat dit die Christelike teologie dwing om oor 'n eie identiteit te gaan besin en selfs die teologie daarvan te verander.

'n Hegemoniese gesindheid: die holocaust het 'n lelike eienskap van die Christendom aan die lig gebring. "Christian theology has begun to confront an element of evil within itself that was brought about by an exclusivist and self-legitimizing world view that failed to value the existance and theological value of others" (Sweeney 1998:146). Die houding van die Christendom, veral teenoor die Jode, was dié van intellektuele hegemonie, super-sessionisme en die hoogwaardigheid om te meen dat slegs Christene die waarheid in pag het. Na die holocaust is dit nie langer moontlik om die Christendom as moreel superieur aan die Jodedom te sien nie.

Die Christendom het met die illusie geloop dat dit onomstootlike vastighede in die Bybel kan vind. Die konfrontasie met die Jode en die bereidheid om hulle as gelyke gespreksgenote te erken, het Christene weer by die ontdekking uitgebring dat "[T]he deconstructive dialectic of the Hebrew scriptures is indeed characteristically and intransigently Jewish in its openness to ambiguity and contradiction" (Brueggemann 1997:7). Omdat dit "definitional in this material to resist closure" (Brueggemann 1997:7) is, het die lees van die Bybel in gesprek met die Jode, die Christene forseer om weer te gaan kyk na hoe daar in die Bybel geteologiseer word. Die materiaal loop langs die weg van 'n eindelose dialektiek tussen bevestiging en negering en sluit enige gearriveerde absolutisme by die wortel af.

Vervreemding van die werklikheid: Die shoah het die Christendom ook gekonfronteer daarmee dat dit geneig is om 'n tipe teologie te bedryf wat onbetrokke by die werklikheid is en wat meen dat teologie onaangeraak by gebeure soos hierdie kan verbygaan (vgl Rendtorff 1993:160). Daar is summier aanvaar dat Jesus se opstanding die kerk op 'n vlak gestel het wat verhewe is bo die alledaagse geskiedenis en ander gemeenskappe en godsdienste (vgl Pawlikowsky 1992:165v). Die krisis van die skeiding tussen tussen die historiese en die eskatologiese is opgehef.

Die aanklag uit die holocaust is dat die godsdiens wat sigself beroep op iets nuuts, danksy die opstanding van Christus, niks nuuts gebring het nie. Die Christene het gelewe asof hulle reeds in die toekoms is, maar intussen al die foute bly maak wat by alle ander mense in die geskiedenis voorkom. Die falsifikasie van hierdie houding 
is geloods vanuit die gebeure van die shoah: "The authentication ... that the resurrection of Jesus cannot in fact embody eschatological fulfillment, even a fragmentary realization, lies in that event's contribution to the deaths of millions of human beings, including great numbers of small children" (Eckardt 1990:165).

Vir Rendtorff (1993:161) noodsaak dit baie indringend skuldbelydenis en 'n proses van teologiese selfrefleksie oor eie kerklike identiteit en teologiese betrokkenheid by die werklikheid. Rebecca Chop sluit by hierdie pleidooi aan. Vir haar werk die literatuur van die holocaust en die bevrydingsteologie saam "... to create new theological space, which in turn forces upon Christianity a fundamental reworking of its theological framework' (Pawlikowsky 1992:168). Vanuit feministiese teologie (kyk o a Rosemary Ruether, Elisabeth Schüsler Fiorenza en Rebecca Chop) word 'n terugkeer na die realiteit van die geskiedenis bepleit. Vir Chop is die belangrikste uitwerking van die holocaust die oproep dat die Christelike teologie moet terugkeer na die "... concrete historical matrix of its original Jewish roots" (Pawlikowsky 1992:168). Eckardt wys ook op die rol wat feminisme kan speel in die gesprek met die Jode en die Bybelse Teologie wat daaruit voortspruit. Die sensitiwiteit in feminisme vir marginalisering as gevolg van magstrukture wat aan manlike groepering en simbole verbind is, kan lei tot epistemologiese verandering in teologiese denke. Daar is 'n sterk ooreenkoms tussen Christelike imperialistiese antiSemitisme en karakteristieke manlike chauvinistiese gedrag. Feminisme kan die teologie van die kerk help bevry van anti-Joodse patriargale imperialisme en meehelp om teologie selfs te begin formuleer in terme van die Jood en die Joodse agtergrond van die Bybel (vgl Eckardt 1990: 165-177).

\subsection{Die uitwerking op die Bybelse Teologie}

Hierdie gedagte van 'n terugkeer na die "Jewish roots" (Pawlikowsky 1992:168) word deesdae baie ernstig opgeneem in die geledere van beoefenaars van die Bybelse Teologie. Sowel vanuit Nuwe-Testamentiese as Ou-Testamentiese hoek word baie aandag gegee aan die Joodse konteks van die Bybel. Jesus tree soos 'n tipiese Joodse leermeester op in die kommunikasiestyl van spreuke en gelykenisse. Hy fokus op tipiese Joodse temas, soos die koninkryk van God, wat uit die Ou-Testamentiese belydenis van God se koningskap voortvloei en deur sy voorgangers en navolgers in 'n apokaliptiese rigting gestuur is. Sy etiese onderrig moet in terme van die begrip van die koninkryk verstaan word. Sy opstanding word in terme van die Joodse geloof 
ervaar en bely as 'n opstanding van die hele persoon. Alles wat oor Jesus bely word, moet dus in Joodse terme gesien word.

Die beweging is om Jesus en die Nuwe Testament binne die konteks van die eerste-eeuse Judaïsme te sien en te verstaan. Die bronne daarvoor is die jonger geskrifte in die Ou Testament, die apokriewe, pseudepigrawe, Dooie Seerolle, Josefus, Filo en die rabbynse geskrifte. In die ontmoeting van Jesus as historiese figuur en as lewende realiteit vandag kry ons met die "Jewishness of Jesus" te doen. "Focus on his Jewishness seems to constitute a way forward in Christology" (Harrington 1991: 85). Küng meen selfs dat sulke spreke oor Jesus "van onder", in plaas van die tradisionele ontologiese taal "van bo" (vanuit sy Godheid), die gesprek met die Jode kan dien en hulle van die Jesus-van-die-kultuur wat hulle ken, by die Jesus-van-die-geloof, kan uitbring en selfs ons eie belydenisformulering kan verander.

Die vergelyking van die Nuwe Testament met kontemporêre Joodse materiaal bring talle nuwe gesigspunte na vore. Strecker (1991) gaan in die "bergpreek" na hoe Jesus self die Tora gebruik en hy vergelyk dit met wat Matteus daarvan gemaak het; wat meer aansluit by Jakobus as by Paulus. Hy werk met die "multivoiced choir of New Testament writers" met "all of the assertions of the New Testament canon" (Strecker 1991:47). Koch (1991) sien in die Nuwe Testament enersyds en die rabbynse Mishna en Talmoed andersyds die voortsetting van die gemeenskaplike literatuur van die Tora. Wanneer hierdie saak in die lig van die sosio-historiese raamwerk van die tyd gesien word, dien dit die gesprek tussen Jode en Christene.

In die Rezeptionsgeschichte word dit duidelik dat Jode en Christene aansluit by ' $n$ teenstrydende tendens wat reeds in die jonger boeke van die Ou Testament aanwesig is. Die Christendom sluit aan by die eskatologies-apokaliptiese tendens en die rabbynse Jode by die wetgeoriënteerde tendens. Uit dieselfde kanon het dus twee groepe onder die eksterne omstandigheid van die verwoesting van die tempel in $70 \mathrm{nC}$ en die interne dinamiek van eie aksente en eiesoortige antropologiese opvattings, elkeen 'n eie kanonversameling laat uitbou. Koch (1991:242) staan dit voor dat langs hierdie weg 'n Bybelse Teologie uitgebou word met "... nicht weniger, sondern mehr historisches Bewusstsein, als es bisher der Bibelwissenschaft zuhanden ist."

Die bewuswording dat die Joodse gemeenskap van daardie tyd uiters divers was, open die moontlikheid vir meer genuanseerde studie. Hoewel die tempel in Jerusalem tot by die verwoesting daarvan, die gemeenskaplike sentrum van die godsdienstige lewe van die Jode was, was daar was 'n minimale eenheid in belydenis. 
Daar word daarom toenemd genuanseerd onderskei tussen die Judaïsme van vór 70 n $\mathrm{C}$ en die Farisees-rabbynse Judaïsme, soos gevorm deur die rabbis en die literatuur waarin hulle leerstellings opgeneem is (die Mishna, Palestynse en Babiloniese Talmoeds, Targoems, midrashim) en die moderne Jodedom wat daarop aanspraak maak dat hulle die voortsetting van laasgenoemde is (vgl Pawlikowsky 1992:162-164). Die latere rabbynse Judaïsme is nie noodwendig die materiaal van waaruit die konteks van Jesus afgelei kan word nie. Hedendaagse Joodse denke word ook grotendeels bepaal deur die holocaust en die staatwording van Israel en is nie gelyk aan die Joodse konteks waarmee gewerk moet word nie. Dit is slegs 'n parallele ontwikkeling langs die Christendom van die eerste-eeuse Jodedom.

Hiermee saam loop die teologiese vraagstuk van God se verbond met die Jode, ook met die Jode van vandag. Harrington redeneer in hierdie verband vanuit 'n voortgaande verbondsverhouding wat God in verskillende vorms bly handhaaf. Die verbond in Jesus is nie plaasvervangend vir die oue nie, maar eerder organies uit die oue terwyl die oue steeds gehandhaaf word (Rom 11), maar langs 'n ander weg. Christelike selfidentiteit kan nie langer gebaseer word op die gedagte dat die kerk die totale vervanging is van die uitgediende, geestelik minderwaardige verbondsvolk van Israel nie. Küng (1991:263-4) verwys na daardie gedagte as "pseudo theology" wat die "permanent election of this people" verbykyk. Die eskatologiese dimensie van Jesus se werk laat die ruimte oop vir die voortsetting van daardie verbond wat langse'n ander pad geloop het. Daardie verbond wat God met Israel gemaak het “... retains its integrity and continues to hold an important place in the process of human salvation, however difficult it may be at this juncture to articulate precisely the meaning of its role in contrast to that of Christianity" (Pawlikowsky 1992:161). Hierdie standpunt het bepaalde impliksasies vir die siening van die verhouding tussen die Ou en die Nuwe Testament, waarna ons weldra sal terugkeer.

Die gevaar wat Reuman sien wanneer die Joodse sosio-historiese konteks sowel as die Joods-ideologiese raamwerk in Christologie betrek word, is dat die Hellenistiese aspek (soos destyds by die Biblical Theology Movement) negeer kan word en die Nuwe Testament te Semities gelees word, of die Ou Testament gejudaïseer word en ongedifferensieerd in lyn met die latere Judaïsme gelees kan word (vgl Reuman 1991b:192)

Met hierdie waarskuwing in gedagte, kan die neiging egter gevolg word om op gebalanseerde wyse iets meer te mak van die Joodse konteks van die Bybel. Van der 
Osten-Sacken bepleit 'n beoefening van die Ou-Testamentiese wetenskap wat ook ruimte bied aan bestudering van die rabbynse Judaïsme. Dit behoort volgens hom binne twee of drie geslagte 'n vanselfsprekendheid te wees dat Joodse literatuur inbegrepe is by Bybelse Teologie. Bybelse Teologie behoort die Ou Testament, Nuwe Testament en Rabbynse uitleg in onderlinge dialektiek te hou. "Eine Struktur dieser Theologie, die allein Platz hat für die Rezeption des Alten Testaments im Neuen und nicht für die lebendige Traditions- und Lebensgeschichte der Bibel in jüdischen Volk, dürfte schwerlich über den Stand hinauskommen" (Van der OstenSacken 1991:266).

Brueggemann ${ }^{1}$ bepleit in die lig van die gesprek met die Jode 'n Bybelse Teologie wat prosessief werk met dialektiese temas soos verbond en ballingskap, loflied en klaaglied, teenwoordigheid en teodisee. Dit is temas wat hoofsaaklik aan die Ou Testament ontleen is. In effek beteken dit dat daar baie groter betekenis aan die Ou Testament in Bybelse Teologie gegee sal word as tot hiertoe. Die beklemtoning van die Joodsheid van Jesus beteken vanself dat daar groter betekenis aan die $\mathrm{Ou}$ Testament gegee sal word. Sy hele lewe en werk is ingeweek in hierdie wêreld. Dit is Pawlikowsky (1992:156) se oortuiging dat “... without deep immersion into the spirit and content of the Hebrew Scriptures the Christian theological student is left with a truncated version of Jesus' message and hence an emasculated version of biblical spirituality." Dit is ook insiggewend hoe die Ou Testament funksioneer by bevrydingsteoloë, soos onder andere Guttierrez.

'n Super-sessionistiese houding wat geen konstruktiewe betekenis aan die Jode gee, of wat die Ou Testament degradeer tot die periferie van 'n afgehandelde voorafskaduwing, is nie langer geldig nie. "If the Hebrew Scriptures are to move to center stage in the faith expression of Christians - as they were for Jesus himself -then these scriptures must begin to assume the status of primary - not peripheral - resources in the overall theological curriculum" (Pawlikowsky 1992:157). Pokorny (1993:91) sien dit as gelykberegtiging: "The New Testament was canonized neither as a substitute for the Jewish Bible, nor as its continuation, but as its counterpart." Rondom die konsep van "counterparts" kan die Ou Testament as selfstandige entiteit bydra tot Chrisțelike teologie sonder om dit afhanklik te stel tot slegs wat Nuwe Testament

\footnotetext{
1 Vgl hier die vergelyking van Olson (1998) tussen Brueggemann en Childs en sy korreksie op albei vanuit Bakhtin se "pervasive dialogical quality of reality" waarvolgens sin in die konteks van dialoog in die alledaagse werklikheid gevind word.
} 
outeurs eksplisiet daarvan gemaak het. Ook die artikulering van inhoude van die $\mathrm{Ou}$ Testament in 'n Bybelse Teologie sal in die lig van die gesprek met die Jode weer opnuut bekyk moet word. Daar is volgens Sweeney (vgl 1998:148-150) te lank met Wellhausen se ophemeling van die profete en degradering van die post-eksiliese Judaïsme gewerk. Hierdie materiaal moet selfstandig en in eie terminologie hanteer word.

Ideologiekritiek, literêre kritiek en kanonnavorsing het in ooreenstemming met die algemene teologiese tendense, die menslike rol sentraal gaan stel en bepalend gaan maak in die formulering van die teologieë en ideologieë wat in die Ou Testament voorkom. God word vanuit die wêreldse realiteit wat God daargestel het, en vanuit die perspektief van menslike standpunte, bely en beskryf. Die Ou Testament gee verskillende teologiese en ideologiese gesigspunte weer oor die aard en karakter van God, die geaardheid van die menslike ervaring van God en van die wêreld. Dit word telkens geartikuleer vanuit die Judaïsme en die Joodse volk. Die sosiale, ekonomiese en politieke belang van daardie groep is in hierdie geskrifte gereflekteer. Die Ou Testament is "... the product of the Jewish people, and as such reflect the concerns of a living people who developed and expressed their view on God, the character of the world and the states in which they lived, and their own role in it, in relation to the diverse factors which characterize any living human society" (Sweeney 1998:154).

Om by die universalistiese verby te stuur en op die Joodse partikularistiese te konsentreer, het aansienlike implikasies vir die vertolking van die $\mathrm{Ou}$ Testament in die Christendom, die siening van die verhouding tussen Ou Testament en Nuwe Testament binne die konteks van die Christelike Bybel, asook die verhouding met die Jode. Dit hou in dat materiaal uit die Ou Testament, gelees en verstaan vanuit die Joodse agtergrond daarvan, goeie teologiese boustene kan bied vir die formulering van 'n eietydse skuldbelydenis. Vanuit die universalisering van sonde en skuld in die Nuwe Testament kan teruggelees word na die partikularistiese in die Ou Testament. Dit sal in die lig van die tendense in die teologiebeoefening en die Bybelse Teologie die moontlikheid skep om die historiese realiteit volledig in ag te neem en 'n belydenis te formuleer wat teologies en kontekstueel konkreet is. 


\section{SKULDBELYDENIS IN VIER GEBEDE}

\subsection{Skuldbelydenisse in die Ou Testament}

Vir Kessler (1996) het die Ou Testament inspraak in die formulering van 'n skuldbelydenis. Dit is self die resultaat van katastrofes, soos die vernietiging van Jerusalem. Dit bied op baie plekke die nadenke oor die aandeel van mense aan daardie gebeure en hulle skuld daaraan. Veral die gedeeltes waarin daardie skuld bely word en die Bybelskrywers "... dies in kollektiven Schuldbekenntnissen ausformulieren" (Kessler 1996:31), is van belang. Van al die moontlike wyses waarop 'n skuldbelydenis geformuleer kan word, sluit Kessler hom aan by die manier waarop dit gedoen is in Psalm 106, en die gebede in Esra 9:6-15; Nehemia 1:5-11; Nehemia 9:6-37 en Daniël 9:4-19. In hierdie bepaalde gedeeltes kom daar vir hom twee eienskappe na vore wat by 'n eietydse skuldbelydenis tuishoort:

- Skuld word bely as oortreding wat deur die loop van die geskiedenis begaan is waaraan almal deel het;

- Die kollektiewe skuldbelydenis is nie die afhandeling van die saak nie, maar steeds deel van 'n voortgaande proses.

Belydenis van sonde vind op twee vlakke plaas: op die tussenmenslike vlak en in dialoog met God. Saul en Simeï het hulle skuld bely teenoor Dawid (1 Sam 26:21 en 2 Sam 19:20). Hiskia het sy skuld bely teenoor Sanherib (2 Kon 18:14). Die strekking is in al die gevalle dieselfde: "The sin against the brother or sister is viewed as sin against the Lord and an occasion for confession before God and the seeking of divine forgiveness" (Miller 1994:245). Kessler fokus egter op die saak van kollektiewe skuld. Die gedeeltes wat hy hanteer gaan oor skuld by Israel en die riglyne wat dit bied vir skuldbelydenis van een groep teenoor 'n ander. Omdat hierdie belydenisse nie belydenisse is op die intermenslike vlak alleen nie, maar in wese belydenisse is voor God, verdien dit verdere ontleding.

\subsection{Esra 9:6-15; Nehemia 1:5-11; Nehemia 9:5-37; Daniël 9:4-19, en ter saak- like gedeeltes}

Die basiese patroon (vgl Miller 1994:259) van hierdie belydenisgebede is: 
- 'n verklaring dat daar oortree is;

- aanvaarding van die werklikheid van die oortreding saam met aanvaarding van die werklikheid van God se genade en geregtigheid;

- erkenning van God se reg om te straf en belydenis van sy bereidheid om te vergewe.

Die Stichwort in hierdie gedeeltes is lehitwaddeh (om te bely). Binne die breë kategorie van prose prayer vorm hulle die Gattung van "prayers of penitence" (Balentine 1993:103), “confessional and penitential prayers" (Miller 1994:246), of ook “communal prayers" (Miller 1994:256). Na strekking stem hulle ooreen met die boeteprogram van Salomo se tempelgebed ("the Deuteronomic editor who prays through the voice of the earlier king" - Miller 1994:246) in 1 Kon 8:46-51a (Balentine 1993:103; Miller 1994:246).

In hierdie passasie word ouer gedeeltes, veral uit die Deuteronomistiese materiaal (vgl Balentine 1993:103), gebruik. In die gebede (soos ook in die belydenis in Barug 1:15-3:8 ) word aangesluit by Jeremia 14:20, veral by die tema van "solidarity in sin with previous generations" (Miller 1994:256). In die gebruik van die materiaal is dit opvallend dat: "... offensichtlich kommte es dem Verfasser auf dem Inhalt, nicht die genaue Formulierung der Unheilsweissagung an" (Mathys 1994:30). In Esra 9:10-12 is 'n "Collage von nicht wörtlichen Zitaten und Anspielungen aus verschiedenen alttestamentlichen Texten" (Mathys 1994:30).

In Daniël 9 (vgl Pilgaard 1994) word die woorde van Jeremia 25:12 en 29:10 oor die herstel van Jerusalem vanuit 'n apokaliptiese denkraamwerk enersyds gediskontinueer deur uitdrukking en inhoud so te skei dat die betekenis nie langer ontsluit kan word nie, maar andersyds gekontinueer deurdat die empiriese wêreld op die transendente wêreld van God betrek word. Deur terug te kyk op die geskiedenis vind Daniël die universele van die geskiedenis, sodat die hede betekenis kan kry in die lig van God se beheer oor die geskiedenis en die kulminering daarvan wanneer Hy alles oorwin en die gelowige bemoedig kan word om in geloof te volhard. Hoewel dit aan Jerusalem verbind word, gaan dit egter by die herstel van die tempel verby na 'n heropbou van kosmiese omvang. Juis deurdat die woorde nie vervul word nie, word dit op die transendente gewerp en word dit 'n woord wat sin gee aan verskillende gebeure daarna. Ekstern is die uitsprake van Jeremia en Daniël in verskillende histo- 
riese kontekste gelewer wat in mekaar se verlengstuk lê. Intern is daar egter 'n "... 'innere' Bedingung ... die in der Tradition enthaltenen Zeugnisse von Gott wirken auf neue Kontexte ein als Verstehenhorizonte, die neue Zeugnisse von Gott mitprägen" (Pilgaard 1994:181).

Ons het hier met doelbewuste skeppings te doen wat 'n bepaalde teologiese blikpunt verwoord. Mathys (1994:4) noem Nehemia 9 'n "systematische, durchkomponierte Gebet”. Hier is ' $n$ “... bedeutenden, sorgfältig formulierenden Theologen am Werk" (Mathys 1994:17-18), 'n "Systematiker von hoher Gestaltungskraft “ (Mathys 1994:20). Hoewel daar sprake is van 'n perspektief op Skrifleer in die gedeeltes, is dit eerder die sondebegrip wat in die teologiese fokus staan. Die gebede kom in "theologisch zentralen Punkten" (Mathys 1994:31) ooreen. Hulle het 'n "common theoretical basis for penitence analogous to those described by the Deuteronomistic editors" (Balentine 1993:103).

Die sondebegrip in die gebede is egter nie dié van Jeremia 31:29 en Esegiël 18:2 van die vaders wat groen druiwe eet en die kinders ly daaronder nie. Daar is eerder "... a sense of solidarity with the people on the part of the ones who pray and with the predecessors on the part of the people ..." (Miller 1994:256). Die verantwoordelikheid vir die sondes van die vaders word vrywillig deur die nuwe geslag oorgeneem (vgl Neh 9:18). Dit blyk ook uit die verskynsel dat in al die gebede daar begin word met die eerste persoon enkelvoud en oorbeweeg word na die eerste persoon meervoud. Daar is "... a sense of continuity with the sins of the ancestors" (Miller 1994:256). Hier is geen skeiding tussen die skuld van die vaders en die skuld van die huidige geslag of ' $n$ meegaande verontskuldiging en beskuldiging van die ander nie. Dit gaan hier om “... Schuld in der Geschichte” (Kessler 1996:37), om “... die Kontinuität der Schuldgeshichte” (Kessler 1996:37). Mathys (1994:18-9) meen dat in Nehemia 9

... macht sich möglerweise also eine neue Einstellung zur kollektiven, generationenübergreifenden Schuldverhaftung geltend: nicht mehr fragloses Hinnehemen oder leidenschaftliches Bekämpfen, sondern bewußtes, freiwilliges Bejahen; der Begriff "Schuldverhaftung" wäre dan verfehlt. Neh 9 zeugte also von einem theologisch gleich reifen und tiefen Umgang mit Sünde wie etwa die Gottesknechtlieder. 
Die skuif in sondebegrip loop ook saam met die ontwikkeling wat die genre van die klaaglied hier ondergaan het. Anders as in die klaagpsalms is hier geen poging tot selfverontskuldiging of bevraagtekening van God se bedoelings nie. In pleks van beklaging val die klem hier eerder op skuldbelydenis (vgl Balentine 1993:116). Die sonde wat hier in solidariteit met die vaders bely word, is egter nie net abstrak of universeel nie, maar baie konkreet.

Die basiese formule in alle belydenisse in die Bybel is altyd: ek/ons het gesondig (vgl Miller 1994:250). Belydenis van skuld gaan hier ook eerder saam met bepaalde oortredings as met die algemene toestand van sonde, omdat teenspoed altyd herlei word na 'n bepaalde oortreding. Miller (1994: 247) merk op dat “... it must be kept in mind that when sins were confessed in the face of disaster, not only was the disaster real but the sins were real." In Esra is dit Israel wat skuld op hulle self gelaai het deur hulle huwelike met nie-Jode. In Nehemia 9 het Israel nie oor die jare God se wet gehoorsaam nie en hulle het gevolglik slawe geword in die land wat God aan hulle vaders gegee het ( $v g l$ Neh 9:36). Hoewel die sondebelydenis in baie algemene terme gestel word in Daniël 9 en tot vervelens herhaal word in verse 8, 9,11,14,15, is dit “... general confession for specific acts of sin" (Miller 1994:249). Hoewel die eksplisietheid van die oortreding ontbreek en gewoonlik uit die narratiewe raamwerk afgelei moet word, is die aanhoudende herhaling met verskillende variasies in Daniël 9 'n tegniek om "... die Schuldverfallenheit Israel in ihrem ganzen Ausmaß und in ihrer Tiefe deutlich zu machen" (Mathys 1994:22). In die lig van die konkreetheid van die oortreding wat nie met eksplisiete verwysings nie, maar met literêre tegnieke aangedui word, is Mathys (1994:27) oortuig dat hierdie gedeeltes in die uitleg betrek moet word op die "Schuldverfallenheit des Menschen und konkrete Schuld hinweisen" (my beklemtoning).

Die teologiese speerpunt van hierdie belydenisse lê egter in die manier waarop die skuldbelydenis geprofileer en teologies gekontekstualiseer word deur dit ten nouste te koppel aan die belydenis van God se geregtigheid, barmhartigheid en genade. Eerstens word iets van die skuld van Israel uitgedruk in terme van hulle verhouding met God. Die geregtigheid van God en die ongeregtigheid van die volk word in jukstaposisie geplaas om die omvang van Israel se sonde uit te druk. Deur die retoriese struktuur word God se deugde met Israel se mislukking kontrasteer. Israel se oortreding word deur die kontras opgeblaas (vgl Balentine 1993:108). Die belydenis van God se regverdigheid “... controls and shapes the penitential elements in the 
prayer" (Balentine 1993:112). Deur die poëtiese spel in die gebede met die verskillende betekenisnuanses van die Hebreeuse stam $s d q$ (God se geregtigheid) word "... the blame of the sinner with the blamelessness of the divine judge" (Miller 1994: 252) gekoppel. Die skuld van Israel word geartikuleer in terme van God se geregtigheid: "[T]he theme of penitence attains clarity by being contrasted to a governing emphasis on God's sovereignty, mercy and justice" (Balentine 1993:104).

Tweedens bely dit omgekeerd weer die geregtigheid van God in terme van die skuld van Israel. "The justice and mercy of God are complexly interrelated in the way in which the Lord deals with a sinful people" (Miller 1994: 259). Die klem val eintlik in die belydenisgebede op God. Miller (1994:257) vervang in sy formulering van die gebede die ongeregtigheid van Israel met die saak waarop dit vanself uitloop in die ontmoeting met die God van geregtigheid, naamlik 'n pleidooi om vergifnis: “Theologically, the heart of these prayers is to be found in their juxtaposition of a clear acknowledgement of the justice and rightness of God's judgment with an appeal to the mercy of God."

Skuldbelydenis word hier eintlik geloofsbelydenis. In hierdie gebede het ons 'n voorbeeld van "... the art of divine characterization" (Balentine 1993:116). Die Kyrie eleison van die gebede word wesenlik 'n gloria in exelcis. Skuldbelydenis en doksologie loop hier hand aan hand (vgl Balentine 1993:109). En dit is teologies die wesenlikste saak in hierdie gebede: skuldbelydenis is in die verhouding met God eintlik geloofsbelydenis.

Gelees vanuit Van Oorschot (1994) se gebruik van die metode van Rollendichtung, word dit die wesenskenmerk van die geloofsgemeenskap dat hulle hulle skuld sien in die lig van die geregtigheid van God en dat hulle hulle geloof in God wat regverdig, barmhartig en genadig is, bely in die lig van hulle bede om vergifnis. Die drie gebede in Esra 9, Nehemia 9 en Daniël 9 nooi die leser uit tot 'n geloofsoriëntasie wat tussen die pole van gerig en heil uitgeleef word. Rollendichtung is 'n leesstrategie waarvolgens die literatuur gelees word as “... ein präzises Leitbild für die Glaubenshaltung eines rechten Israelit" (Van Oorschot 1994:70). Lesers identifiseer hulleself met Esra, Daniël en die Leviete en die belydenis wat in hierdie gebede uitgespreek word. Soos hulle word die leser oortuig dat “... [D]ie Einwilligung in Jahwes Gericht... befreit zu neuer Erfahrung der Nähe Gottes" (Van Oorschot 1994:80). 
In Nehemia 9 word die geloofsgemeenskap op 'n bepaalde manier geskets. "Die ineenvlegting van lof aan God en belydenis van eie skuld in sigbare beleefbare vorm, is die kenmerk van die geloofsgemeenskap wat hier uitgebeeld word" (Venter 1995:730). Hierdie gemeenskap “... het 'n bykans tweeslagtige aard waarin vreugde en smart, hoop op God en skuldbelydenis voor God sy aan sy staan ..." (Venter 1995: 729). Ook in Daniël 9 waar die gebed (Dan 3-19) in montage met die omraming (Dan $1-2 ; 20-27)$ staan, word twee aspekte in jukstaposisie geplaas. Dit dra die boodskap: "Die houding wat die gelowige moet inneem, is om volledig op God te vertrou en in gebedstoewyding sy volgehoue vertroue op God te vestig" (Venter 1997:345). Skuldbelydenis word hier apokalipties geprojekteer op God se geregtigheid en barmhartigheid wat die enigste sekuriteit vir die toekoms bied.

Hierdie dialektiek pas ook in by die tweede van die drie rubrieke waarvolgens Brueggemann 'n Bybelse Teologie wil skryf. Onder sy kategorie "Hymn and Lament" (Brueggemann 1997:6) werk hy met die begrippe core testimony en counter testimony ( $\mathrm{vgl}$ die begrippe meesternarratiewe en kontranarratiewe by Breytenbach 1997). Volgens Brueggemann (1997:6) word “... the core testimony of hymns ... endlessly accompanied by complaint and lament that subvert the great doxological claims." In hierdie geval ondermyn die skuldbelydenis nie die doksologie nie, maar gee in die jukstaposisie daarmee 'n ryker betekenis aan die doksologie.

In die Nuwe Testament word belydenis van skuld in die vorm van 'n gebed voortgesit (vgl Joh 5:15-16). In lyn met die tendens hierbo word die beroep op onskuld daar nog veel kleiner. Daar is “... a move toward confession of general unworthiness as well as unworthy and sinful acts" (Miller 1994:260). Alle mense het sonder uitsondering gesondig. In Jakobus, die evangelies en Handelinge is daar egter wel sprake van bepaalde oortredings. In sulke gevalle "it may be necessary to identify them for the community" (Miller 1994:261). Die skuld van alle mense word hier in die kruisgebeure bevestig, maar tegelykertyd deur die geregtigheid, genade en barmhartigheid van God in God se Seun vergewe.

Pilgaard (1994) illustreer dit aan die hand van die Daniël-midrash van Markus 13. Hy werk met die kontinuïteit en diskontinuïteit tussen die getuienisse van die $\mathrm{Ou}$ Testament en die Nuwe Testament. In Markus word die apokaliptiese moment van Daniël paraneties omgeswaai omdat Jesus wat die toekomswoord praat, dit nie uit die hemel doen nie maar in sy eie persoon. Jesus self word die draer van daardie heilsgeskiedenis waarvan Daniël getuig het. "Die grundlegende Kontinuität zeigt sich aber 
in den Zeugnis von Gottes Treu zu seiner Verheissung" (Pilgaard 1994:200). Skuldbelydenis en doksologie wat saam in Daniël apokalipties geprojekteer was, word hier in Jesus paraneties gechristologiseer.

Sowel die algemene sondigheid van individue of groepe en hulle bepaalde konkrete skuld word in Christus bely in die selfde asem en juis tot eer en lof van sy Naam. Skuldbelydenis staan nooit geïsoleer nie, maar altyd in die nouste samehang met die belydenis van geloof in God.

\section{SLOTSOM}

In die lig van die tendens in teologie na praktyk en pluriformiteit, die benutting in Bybelse Teologie van die gesprek tussen Jode en Christene en die leidrade in die gebede waarin skuld en geloof in mekaar swaelstert, kan 'n skuldbelydenis moontlik soos volg lui:

Ons bely ons geloof in God wie se geregtigheid, barmhartigheid en genade ons in Jesus Christus leer ken het. Ons bely ons skuld dat ons nie die nuwe lewe van geregtigheid, barmhartigheid en genade voor en teenoor ander uitgeleef het nie. Ons het deur ons individuele en kollektiewe deelname aan die stelsel van apartheid, doelbewus of onbewus in versuim gebly om die geregtigheid van Christus uit te leef en het daarom deel gehad aan die belemmering van die welwese van ons gemeenskap en die mensontering van baie mense met wie ons in Suid-Afrika saamleef. Ons bely ons volkome afhanklikheid van die genade van God en ons bid saam met elke mens in hierdie land vir God se vergifnis in Jesus Christus en vir die teenwoordigheid van God se Gees in ons lewe, wat ons tot groter offervaardigheid, onderlinge liefde en verdraagsaamheid sal lei.

\section{Literatuurverwysings}

Balentine, S E 1993. Prayer in the Hebrew Bible: The drama of divine-human dialogue. Minneapolis: Fortress Press.

Breytenbach, A P B 1997. Meesternarratiewe, kontranarratiewe en kanonisering: 'n Perspektief op sommige profetiese geskrifte. HTS 53(4), 1161-1186.

Brueggemann, W 1997. Biblical theology appropriately postmodern. BTB 27(1), 4-9. 
Charlesworth, J H (ed) 1990. Jews and Christians. New York: The Crossroad Publishing Company.

- 1991. Jesus' Jewishness: Exploring the place of Jesus within early Judaism. New York: The American interfaith institute.

- 1992. Overcoming fear. New York: The Crossroad Publishing Company

Deist, F E 1992. South African Old Testament studies and the future. OTE 5, 311-331.

Den Hertog, C 1996. Het zonderlinge karakter van den Godsnaam: Literaire, psychoanalytische en theologische aspecte van het roepingsverhaal van Moses (Exodus 2.23-4.17). Zoetermeer: Boekencenrum.

Dreyer, Y 1998. Pastorale interaksie met vroue: 'n Prakties-teologiese begronding. DDProefskrif, Universiteit van Pretoria.

Eckardt, A R 1990. Salient Christian-Jewish issues of today: A Christian exploration, in Charlesworth 1990:151-177.

Frostin, P 1988. Liberation theology in Tanzania and South Africa: A first world interpretation. Lund: Lund University Press. (Studia Theologica Lundensia 42.)

Harrington, D J 1991. The Jewishness of Jesus as an approach to Christology. Biblical theology and Christian-Jewish relations, in Reuman 1991:71-86.

Juel, D 1994. Brevard Childs and the truth of the Bible. Dialog 33(2), 94-98.

Kessler, R 1996. Das kollektive Schuldbekenntnis im Alten Testament. EvTh 56(1), 2943.

Koch, K 1991. Der doppelte Ausgang des Alten Testaments, in Jahrbuch für Biblische Theologie (JBTR), Band 6: Altes Testament und Christlicher Glaube, 215-242. Neukirchen-Vluyn: Neukirchener Verlag.

Küng, H 1991. Christianity and Judaism, in Charlesworth 1990:258-269.

Kysar, R 1991. Preaching as Biblical Theology: A proposal for a homiletical method, in Reuman 1991:143-156.

Mathys, H-P 1994. Dichter und beter: Theologen aus spätalttestamentlicher Zeit. (Orbis Biblicus et Orientalis 132.) Göttingen: Vandenhoeck \& Ruprecht. 
Miller, P D 1994. They cried to the Lord: The form and theology of Biblical prayer. Minneapolis: Fortress Press.

Olson, D T 1998. Biblical theology as provisional monologization: A dialogue with Childs, Brueggemann and Bakhtin. Biblical Interpretation 6(2) 162-180.

Pawlikowsky, J T 1992. Redefining the role of Jews and Judaism in Christian theological education: A continuing challenge, in Charlesworth, 1990:153-171.

Pedersen, S (Ed) 1994. New directions in Biblical theology: apers of the Aarhus Conference, 16-19 September 1992. Leiden: Brill.

Pilgaard, A 1994. Apokalyptik als bibeltheologisches Thema: Dargestellt an Dan 9 und Mk 13, in Pedersen 1994:180-200.

Pokorny, P 1993. The problem of Biblical theology. Horizons in Biblial Theology 15(1), 83-94.

Rendtorff, R 1993. The impact of the holocaust (shoah) on German Protestant theology. Horizons in Biblical Theology 15(2), 155-167.

Reuman, J (ed) 1991. The promise and practice of biblical theology. Minneapolis: Fortress Press.

Reuman, J 1991a. The promise of Biblical Theology: Some current and new perspectives, in Reuman 1991:1-31.

- 1991b. Afterword: Putting the promise into practice, in Reuman 1991:185-208.

Strecker, G 1991 The law in the sermon on the mount, and the sermon on the mount as law, in Reuman 1991:35-49.

Sweeney, M A 1998. Reconceiving the paradigms of Old Testament theology in the pastshoa period. Biblical Interpretation 6(2), 142-161.

Trible, P 1991. Five loaves and 2 fishes: Feminist hermeneutics and biblical theology, in Reuman 1991:51-76.

Van Aarde, A G 1995. Kerk en teologie op pad na die derde millennium: 'n Paradigmatiese verskuiwing van middelmatige aard. HTS 51(1), 13-38.

Van Oorschot, J 1994. Nachkultische Psalmen und spätbiblische Rollendichtung. ZAW 106, 69-86. 
Van der Osten-Sacken, P 1991. Der Wille zur Emeuerung des christlchenjüdischen Verhältnisses in seiner Bedeutung für biblische Exegese und Theologie, in Jahrbuch für Biblische Theologie (JBTR), Band 6: Altes Testament und Christlicher Glaube, 243-267. Neukirchen-Vluyn: Neukirchener Verlag.

Van Wyk, I W C 1997. Moet die Afrikaanse kerke skuld bely oor apartheid? Wat leer ons uit die Duitsers se worsteling met skuld? HTS 53(4), 1399-1436.

Venter, P M 1995. Die aard van die geloofsgemeenskap in Nehemia 9. HTS 51(3), 720 731.

- 1997. Intertekstualiteit, kontekstualiteit en Daniël 9. In die Skriflig 31(4), 327-346.

Von Waldow, H E 1995. The Christian-Jewish dialogue: in the footsteps of Markus Barth. Horizons in Biblical Theology 17(2), 141-164.

West, G O 1991. Biblical hermeneutics of liberation: Modes of reading the Bible in the South African context. Pietermaritzburg: Cluster Publications. (Monograph Series 1.) 